\title{
The importance of voluntary feed intake in pigs
}

\section{By V. R. FOWLER, Rowett Research Institute Bucksburn, Aberdeen $A B 29 S B$}

The voluntary intake of feed by growing pigs has until recently been regarded as a problem for physiologists rather than one which was of concern to the pig producer. This was because the emphasis of the pig industry used to be directed towards the production of sides of bacon, and to produce the required degree of leanness it was necessary to restrict feed intake. A study of the feeding experiments on pigs conducted in the UK during the period from $194^{\circ}$ to the present time shows that a high proportion were concerned with finding optimal feeding scales for growing pigs. The classical experiments of McMeekan at Cambridge (McMeekan, 1940, 194I) were to a large extent responsible for giving authenticity to the strategy of feeding young pigs generously and older pigs very restrictedly.

\section{Reducing voluntary intake}

Restricted feeding often entails additional work and expenditure compared with feeding to appetite because the feed must either be weighed or apportioned volumetrically to each pen. For this reason, bacon producers have been interested in alternative means of reducing intake. One approach is to incorporate in the diet ingredients which dilute the diet or which inhibit the intake of feed. Because the pig has only a very limited capacity to digest cellulose, plant materials, which contain a high proportion of cell wall, tend to be very indigestible. When the diet has these materials added at low levels, the pig may actually increase its intake in an attempt to compensate for a reduction in the digestible energy. However, if the concentration is steadily increased, then a point is reached when the pig can no longer compensate for the diluting effect and the total daily intake is thereby reduced.

The subject has been extensively reviewed over the years (Cole et al. 1972; Braude, 1967, 1972) and it is not my purpose to explore the quantitative aspects in depth. There are, however, some aspects of principle which merit some mention. The addition of materials to the diet which are low in energy, may have an effect on other more positive components in the diet. For example, there may be a reduction in the utilization of protein, because the fibre acts as a sponge holding proteins and amino acids in its structure. It may also block the access of hydrolytic enzymes to the protein and physically prevent hydrolized proteins being presented to the absorptive surfaces of the small intestine (Livingstone et al. 1979; Livingstone, $198 \mathrm{I})$. The problem is not only related to protein but may affect other nutrients, for example zinc. Partridge ( 1978 ) showed that the inclusion of wood cellulose at the rate of $90 \mathrm{~g} / \mathrm{kg}$ diet doubled the faecal excretion of $\mathrm{Zn}$ and substantially increased the faecal losses of phosphorus and magnesium. 
In practice, it is extremely difficult for many commercial units to dispose of the effluent from intensive units, even at its normal rate of production. The increase which would result from the use of indigestible materials would bring additional costs and exacerbate what is already a critical problem.

An alternative approach to reducing intake, is to incorporate unpleasant but non-toxic substances in the diet. Blair \& Fitzsimmons (r970) added a particularly bitter substance known commercially as 'Bitrex' (benzyldiethyl (2,6-xylyl carbamoyl methyl) ammonium benzoate) to the diet. This substance was claimed to be ten to twenty times more bitter than brucine or quassin. Inclusion of this material had no long-term effect on intake even when concentrations reached $50 \mathrm{mg} / \mathrm{kg}$.

\section{Increasing voluntary intake}

For reasons discussed previously, the problem of enhancing intakes has not until recently been considered to be a real one. However, several factors have come together in modern pig production which make it apparent that in some circumstances there could be an improvement in efficiency if the normal daily intakes of digestible nutrients could be increased. First, the newer genetic strains of pig are substantially leaner than hitherto, and with them has come the suggestion from the processing industry that some pigs are too lean for the market. Second, the increasing substitution of castrates by boars, leads to a shift towards leanness in the population and with it an actual reduction in voluntary intake. The daily intakes of digestible energy by boars, castrates and gilts given similar diets at the Rowett Research Institute were 33.4, 37.8 and 37. I MJ respectively (Fowler et al. 1981 ).

It is evident that when a situation is reached when pigs are sufficiently lean, it is no longer possible to increase efficiency by the substitution of energy-rich fatty tissue by lean tissue with a high water content. In this circumstance the only way forward is to improve the rate of production, by increasing feed intake, thereby reducing the overhead costs of production associated with time. An obvious parallel is the broiler chicken and the turkey, where genetic improvement over recent years has been associated with a reduction in number of days taken to reach slaughter weight and an increase in daily feed intake (Abplanalp et al. 1984).

A third factor, but rather less obvious to those with a mainly biological outlook, is the change which has occurred in the technology of processing carcasses. For the bacon market, it was traditional for the side to be marketed whole with no further processing until it was out on a slicing machine in front of the customer. This meant that the adjustment of the ratio, fat:lean was a primary responsibility of the farmer. However, modern methods of packaging, cutting and curing have introduced far greater flexibility within the factory for meeting the needs of the consumer. There are two interesting historical examples of the effect of this approach. In the 1960s, there was a major initiative by an influential processing group to promote the so-called 'heavy hog' (Bellis et al. 1960; Friedlander, 1961). 
Table 1. A comparison of four strategies for lean meat production from pigs based on the values of Braude et al. (1963)

\begin{tabular}{|c|c|c|c|c|}
\hline Feeding... & Restricted & Ad lib. & $\begin{array}{l}\text { Ad lib. } \\
\text { with } \\
\text { protein } \\
\text { supplement }\end{array}$ & $\begin{array}{c}\text { Ad lib. } \\
\text { without } \\
\text { protein } \\
\text { supplement }\end{array}$ \\
\hline Slaughter wt (kg) & $93 \cdot 6$ & 93.9 & $118 \cdot 7$ & $118 \cdot 8$ \\
\hline Total lean in carcass $(\mathbf{k g})$ & $27 \cdot 27$ & $27 \cdot 63$ & 33.55 & 33.09 \\
\hline $\mathrm{kg}$ feed $/ \mathrm{kg}$ lean & I 4 & II.9 & 13.5 & $14 \cdot 7$ \\
\hline $\mathrm{kg}$ feed $/ \mathrm{kg}$ lean (including feed to dam) & $12 \cdot 9$ & $13 \cdot 3$ & $14 \cdot 3$ & I5:3 \\
\hline
\end{tabular}

The purpose was to take pigs which had been fed to appetite to heavy weights and then during processing to direct the lean meat to one market and the fat to another.

A detailed scientific investigation of this approach was conducted by Braude et al. (1963) who examined the biological and economic efficiency of four strategies of pig production. They compared pigs slaughtered at $9 \mathrm{r} \mathbf{~ k g}$ and given feed according to a scale or fed to appetite with pigs slaughtered at $\mathrm{I} 8 \mathrm{~kg}$ and fed to appetite on high- or low-protein diets. The results for feed conversion to lean tissue and for total weight of lean yielded in the carcasses are shown in Table 1.

This experiment was widely held to show the biological and economic inefficiency of both the heavy pig and, incidentally, of feeding pigs ad lib. In fact, the differences in efficiency of the pigs at bacon weight were very small. The questions which arise 20 years on from this experiment are whether, with improved genotypes and diets, the same logic applies. The following is an example derived from the findings of the Commercial Product Evaluation (CPE) scheme of the Meat and Livestock Commission.

\section{Efficiency and feed intake}

The values were those from years 6 to 8 of the CPE tests which included some thirteen companies and a genetic control line which remained unselected for over Io years (Meat and Livestock Commission, 1982).

In Figs $\mathrm{I}-3$ the proportion of lean in the carcass, the daily growth rate of the lean and the feed cost per $\mathrm{kg}$ lean $v$. the daily feed intake for each company are plotted. The two levels of intake were essentially unrestricted feeding and 0.8 of this amount. The values are the company means for pigs growing from about 25 to $88 \mathrm{~kg}$ live weight. As expected, pigs fed to appetite had a lower proportion of lean in the carcass than those fed restrictedly but they grew lean tissue more quickly. This is, in effect, the producer's dilemma. Fig. 3 shows that the average effect of intake on the conversion of feed to lean is quite small with, if anything, the feed cost rising at the higher intake.

At first sight this appears to imply that feeding to appetite is biologically inefficient. This is, however, an incomplete assessment because it fails to take into account the fact that the lean grows faster at the higher rate of intake. The only way to resolve this is to assign a cost value to the input (feed) and to the output 


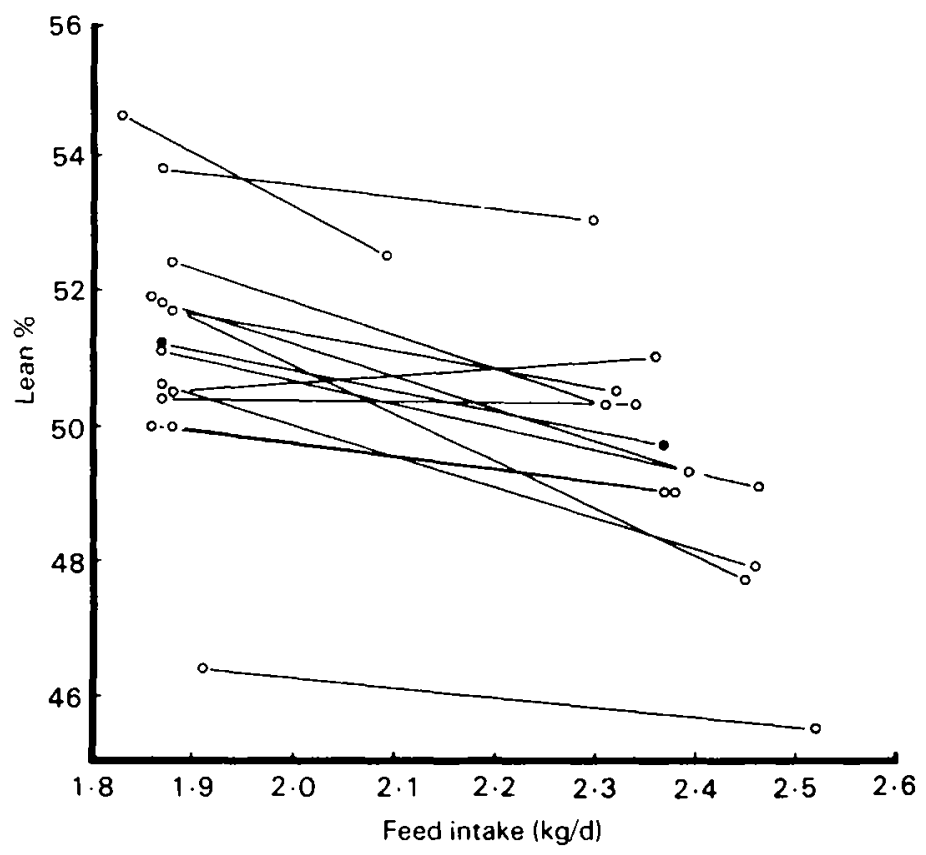

Fig. I. The percentage of lean tissue in the carcasses of pigs kept by thirteen commercial companies at two levels of feeding, calculated from values from the Meat and Livestock Commission (1982). (O), Overall means.

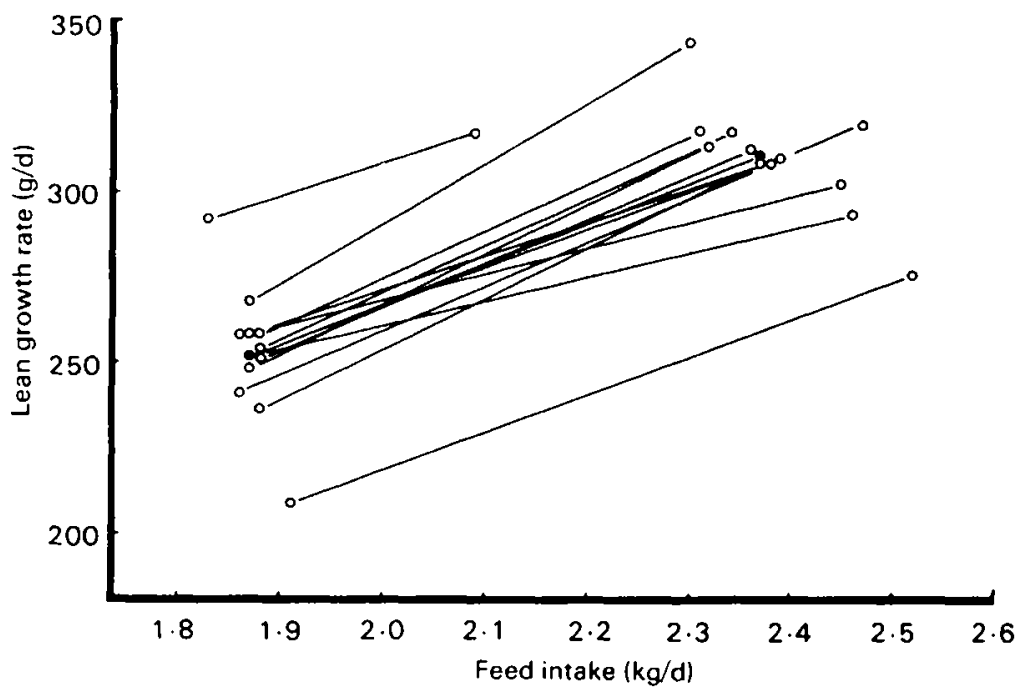

Fig. 2. The growth rate of lean tissue in pigs at two levels of feeding by thirteen commercial companies, calculated from values from the Meat and Livestock Commission (1982). (0), Overall means. 


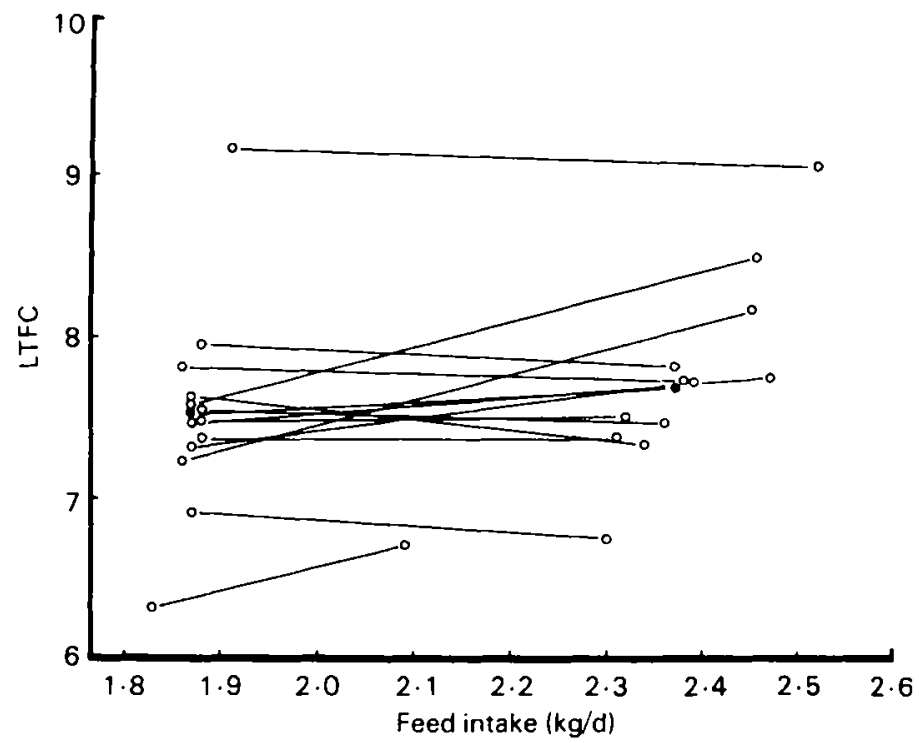

Fig. 3. The feed required ( $\mathrm{kg} / \mathrm{kg}$ lean tissue gain; LTFC) in pigs kept by thirteen commercial companies at two levels of feeding, calculated from values from the Meat and Livestock Commission (1982). (๑), Overall means.

(lean) and calculate the difference between the two per unit of time. The value assigned to lean tissue was $220 \mathrm{p} / \mathrm{kg}$ and to feed $\mathrm{I} 6 \mathrm{p} / \mathrm{kg}$, those being the current approximate prices. No allowance, positive or negative, was attributed to fat, the cost of its removal being assumed to equal its market value as a commodity. In Fig. 4, the average daily margin (lean value - feed costs) for all companies is shown. It suggests that the actual return per pig place/d is considerably greater on feeding ad lib. than on restricted feeding, when payment is on the basis of lean in the carcass.

In Fig. 5 some of the interactions between companies in the response of the margin to feed intake are given, showing that not all responded similarly.

\section{Increasing intake}

The previously-mentioned example shows that in some circumstances the route to the economic production of lean meat is by increasing the intake of pigs. As pigs become even more lean this will become more true. Since limitations on intake have a genetic component it could be that selection for greater efficiency will cause an increase in the voluntary intake. From the example given previously it seems that already the efficiency of many existing strains is limited by intake.

Very few experiments have been made to explore practical methods of improving intake in pigs, under normal environmental conditions. One such approach was to see whether, using relatively practical diets, the apparent increase in feed intake shown in rats by the use of cafeteria feeding reported by Rothwell \& Stock (1982) could be demonstrated in pigs. An experiment was undertaken to provide growing pigs with a degree of novelty at each of nine daily feeds by 


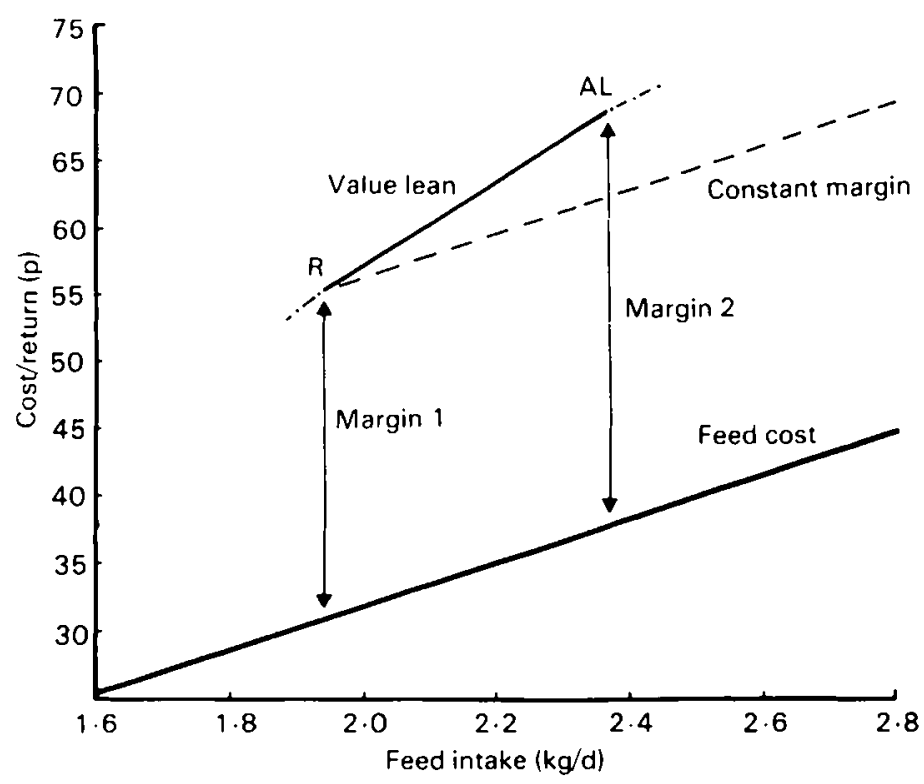

Fig. 4. The relation between the daily cost of feed $(\mathrm{I} 6 \mathrm{p} / \mathrm{kg})$ and the value of lean tissue produced daily $(220 \mathrm{p} / \mathrm{kg})$ for pigs at two levels of feeding: restricted (R) or ad lib. (AL), calculated from values from the Meat and Livestock Commission ( 1982 ).

combining three cereals, wheat, oats and barley, with three sources of protein, fishmeal, soya bean and dried skimmed milk (Fowler et al. 1984).

The group receiving the novel feeds were compared with pigs fed ad lib. on the aggregate diet. The results are given in Table 2.

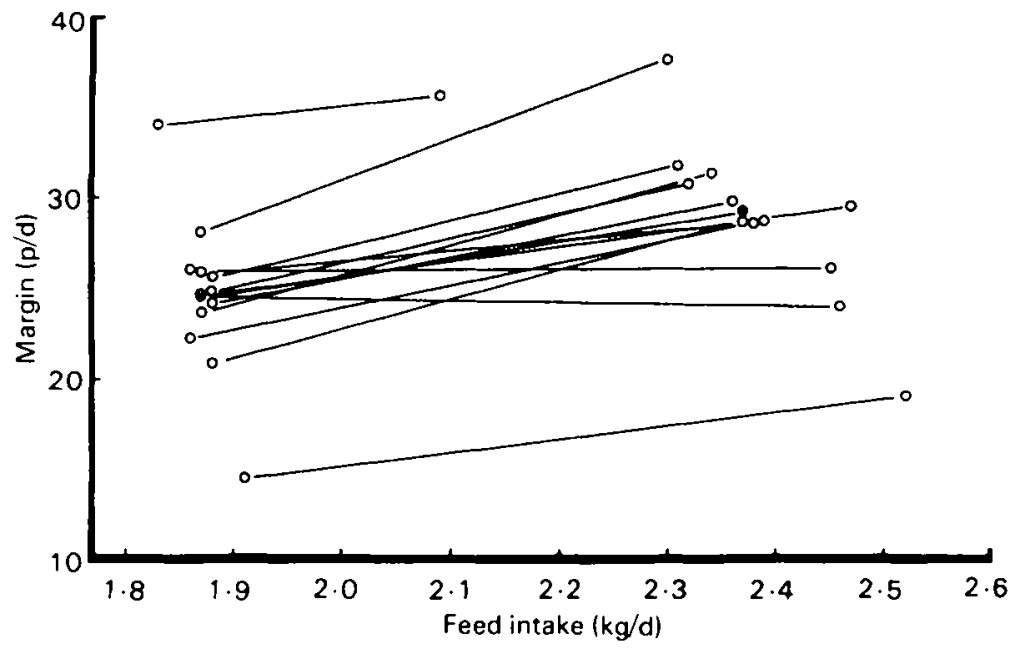

Fig. 5. The margin between feed costs $(p / d)$ and the value of lean tissue produced for thirteen commercial companies feeding pigs at two levels of intake, calculated from values from the Meat and Livestock Commission (1982).(๑), Overall means. 
Table 2. Comparison of feed intake, growth and carcass composition of pigs fed frequently with novel combinations of feed ingredients, presently with the aggregate feed or with the aggregate feed offered ad lib. (values from Fowler et al. 1984)

Feed ...

Daily feed intake (kg)

Daily wt gains $(\mathrm{kg})$

Feed:wt gain

Carcass specific gravity

$\begin{array}{ccll}\begin{array}{c}\text { Frequent } \\ \text { and } \\ \text { novel }\end{array} & \begin{array}{c}\text { Frequent } \\ \text { aggregate } \\ \text { diet }\end{array} & \begin{array}{c}\text { Aggregate } \\ \text { diet } \\ \text { ad lib. }\end{array} & \begin{array}{c}\text { SE of } \\ \text { mean }\end{array} \\ 2.32 & 2.35 & 2.33 & 0.05 \\ 1.033 & 1.061 & 1.061 & 0.03 \mathrm{I} \\ 2.32 & 2.33 & 2.35 & \\ 1.0542 & 1.0535 & 1.055^{\circ} & 0.0026\end{array}$

The treatments had no effect on intake. Earlier attempts to increase food intake by feeding highly concentrated diets also resulted in no effect (Fowler et al. 198 r).

\section{Conclusions}

From this brief review and discussion, it is clear that appetite is important, and will become more so, in determining the efficiency of pig production. In the long term it is likely to be the single most important factor limiting production in the growing pig. It is extraordinary that the physiological mechanisms of its control and the nature of its inheritance are still relatively poorly understood.

\section{REFERENCES}

Abplanalp, H., Tai, C. \& Napolitano, D. (1984). British Poultry Science 25, 343-347.

Bellis, D. B., Friedlander, J. A. P. \& Trenchard, Lord (1960). The Economic Production of Lean Meat. London: J. Wall and Sons Ltd.

Blair, R. \& Fitzsimmons, J. (1970). Animal Production 12, 529-530.

Braude, R. (1967). Proceedings of the Nutrition Society 26, 163-181.

Braude, R. (1972). In Pig Production, pp. 279-291 [D. J. A. Cole, editor]. London: Butterworths.

Braude, R., Townsend, M. J. \& Harrington, G. (1963). fournal of Agricultural Science, Cambridge 61, 200-220.

Cole, D. J. A., Hardy, B. \& Lewis, D. (1972). In Pig Production, pp. 243-257. [D. J. A. Cole, editor]. London: Butterworths.

Fowler, V. R., McWilliam, R. \& Aitken, R. (198I). Animal Production 32, 357.

Fowler, V. R., McWilliam, R., Pennie, K. \& James, M. (1984). Animal Production 38, 535.

Friedlander, J. A. P. (196I). Fournal of Institute of Corn and Agricultural Merchants 10, 21.

Livingstone, R. M. (1981). Animal Production 32, 396.

Livingstone, R. M., Kovcin, S., Atkinson, T. \& Baird, B. A. (1979). Animal Production 28, $437-43^{8}$.

McMeekan, C. P. (1940). fournal of Agricultural Science, Cambridge 30, 51 I-569.

McMeekan, C. P. (I94I). Journal of Agricultural Science, Cambridge 31, I-49.

Meat and Livestock Commission. (1982). Commercial Product Evaluation, Trial 8. Milton Keynes: Meat and Livestock Commission.

Partridge, I. G. (1978). British fournal of Nutrition 39, 539-545.

Rothwell, N. J. \& Stock, M. J. (1982). Fournal of Nutrition I02, $15^{1} 5^{-1} 5^{24}$. 